\title{
Effect Economic Return Performance to Company Financial Evidance From Indonesia
}

\author{
Amir Indrabudiman, Wuri Septi Handayani, Ratih Puspitaningtyas Faeni, Dewi Puspaningtyas \\ Faeni
}

\begin{abstract}
This study aims to analyze the regression analysis model to measure the return rate economically within the company, by using several variable ratio in the company. This study uses the financial statements of companies listed on the BEI for the year ending 2016. In this study proposes a regression analysis model in the measurement of the rate of return of the company economically. From the research that has been done there is no relationship between the rate of return of the company's economy in doing research on variabel financial ratios in use. This is proven by the results of multiple regression test and wald test that shows not many significant variables to the rate of return of the company's economy.
\end{abstract}

\section{Introduction}

See [1-3] for a good and healthy economy of all kinds, in need of parts of the company to be good and healthy as well. Not to mention how the company's financial statements for macro and micro, where at the macro level can contribute to the State and a nation, at the level of the micro level can make employees in the company become prosperous. With this, indirectly macro and micro are profitable and can function in a good business system. By always maintaining the financial and balance in the company, real in need, in addition to the process of globalization that will occur in the State of Indonesia [4-6]. The occurrence of global economic issues can be a national problem and a problem that can also impact the world economy. Like the occurrence of several financial crises in 2008 in Asia, the Indonesian economy is controversial and causes problems. This research is done because this will be the headline news. In this study it is considered important that a balance of finances and assets is an important fact to be discussed. Thus, this study will analyze the impact of economic returns that occur in some companies in Indonesia. In due to the company's goal to get maximum results, then some of the indicators contained in the company's finances made the key in viewing and measuring the company's financial condition [7-8].

\section{Literature Review}

The occurrence of several financial crises related to companies such as those that have occurred in Asia and U.S.A, have indirect impacts on economic and corporate paths in Indonesia. But globally the occurrence of this crisis

Revised Manuscript Received on July 05, 2019.

Amir Indrabudiman,

Lecturer at the Faculty of Economics and Business, Universitas Budi

Luhur, Jakarta, Indonesia,

amir.indrabudiman@budiluhur.ac.id can affect the

company's financial intermediation system in particular. Various corporate sectors occur and are affected by the crisis and affected by this situation. So there is a dependency relationship between the companies both in the country and those outside the country. In this study the empirical model is built in the literature that is guided by a set of indicators contained within the company both micro and macro, which can be influenced and influenced by the financial crisis of the company. Indirectly this factor can cause the macro activities of the company to be disturbed, in because the production process within the company associated with the economic activities of a country. The existence of a very big role by the company to macro economic activities, making the balance that occurs in the micro level is in need for the domestic economy. Several levels of levels that can affect the company's financial health level for microeconomic health in the ratio of profitability, demand and supply factors, and capital adequacy, and to macroeconomic ratios that can also support corporate finance such as bank lending rates, inflation rate index, and the exchange rate of a currency in a State. The study will ultimately provide value within a company's context, which is exposed to its financial activities. Thus, the balance of finance, such as the burden of borrowing and foreign exchange, becomes an easy thing to achieve. The inequalities between assets, liabilities and capital in the company's financial statements, create imbalances that can affect the condition and financial condition of the company. Given this, systemic risk may occur, in part because of Indonesia's economic activity in [1$5]$.

In [9-12] there are several methodologies in use and taxonomically modified methodologies. The model proposed in the study analyzed how the relationship between components and variables of the capital market with economic variables. But there is also a topic about the relationship of economic variables that affect the company with the variables contained in financial markets. In the study found a relationship and reactions to the variables that do research on the economy in real terms and there is a decline in some components of the stock market in the country in doing research. This gives a signal that the variables that are in carefully for the stock market can cause and affect the company's economy. The use of a combined taxonomic index can be considered as a good concordance measure in estimating financial market connectivity with the country's economic activity. Usage The proposed research method gives a signal on the stock market variables that are in use in connection with the capital market component. The study explains significantly the relationship

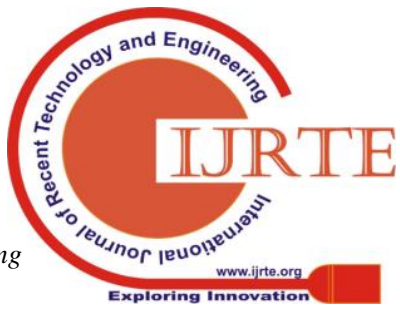


in the medium term and in the long run, and the influence of macroeconomic variables with the short term.

The use of analysis model of profitability can assess and see the condition of financial crisis in the banking industry globally, this study was conducted in several developed countries and developing countries [13-15]. In the study, the model of credit analysis applied in the banking industry at the time of the financial crisis, contributed to the model that has been proposed, especially for developing countries. However, this indirectly raises problem loans in the banking industry more and more, and in theory will decrease the revenue received in the paging sector from credit. On the other hand, there is a need for capitalization and can ultimately influence indicator indicators financially and profitability in the banking industry especially in developing countries.

If the previous research assessed the impact of some variables in the banking sector, but within the macroeconomic and profitability limits of the company using data from 2005 to 2013, and data analysis with panel regression. Based on the model in the proposed regression panel data with fixed effect model to see the relationship of profitability and other banking ratios, in the results can be various effects. The value of liquidity in each have different effects and the process of capitalization and interest rate values significantly influence in the study conducted. While in other component using non-interest cost have negative effect with profitability ratio. It is empirical evidence from the studies that have been done on the use of other variables such as ROA, ROE, and profitability. This study was

conducted in 6 countries located in Central America and in South America. With the increasing value of corporate profitability make the quality of loans that have been given have a double impact with the profitability ratio of the company, resulting in a positive relationship.

\section{Data and Research Method}

In this study the model of proposed multiple regression consisting of variables $\mathrm{Y}$ and $\mathrm{X}$, where $\mathrm{Y}$ is the economic return on asset and income earned by the company $($ Economic return $=\mathrm{ERR})$. While for variables $\mathrm{X} 1$ to $\mathrm{X} 6$ each consist of variables, availability of money (The Good Money $=\mathrm{X} 1$ ), excess operating profit (Gross Profit Surplus $=\mathrm{X} 2$ ), surplus operating profit on the share of return on investment (Rate income return $=$ X3) Cash flows from operating activities are proportional to turnover ratio (CFO / $\mathrm{CA}=\mathrm{X} 4)$, comparison of earnings after interest and taxes versus total income (ebit $=\mathrm{X} 5$ ), return of inventory turnover divided by total debt $(\mathrm{Rdt}=\mathrm{X} 6)$. This research was conducted in April 2017, using the financial statements of companies listed on the BEI for the year ending 2016, as many as 30 company financial statements. This study uses multiple regression analysis with the proposed equation as follows:

$\mathrm{Y} 2016=\alpha+\mathrm{X} 12016+\mathrm{X} 22016+\mathrm{X} 32016+\mathrm{X} 42016+$ $\mathrm{X} 52016+\mathrm{X} 62016$

The attached overview of data for this study is descriptively statistic :

Table 1 : Descriptive statistice research

\begin{tabular}{|c|c|c|c|c|c|c|c|}
\hline & $\mathrm{X} 1$ & $\mathrm{X} 2$ & $\mathrm{X} 3$ & $\mathrm{X} 4$ & $\mathrm{X} 5$ & X6 & $\mathrm{Y}$ \\
\hline Mean & 0.103704 & 12037093 & 0.147222 & 0.070630 & 0.085889 & 2616.148 & 0.123111 \\
\hline Median & 0.058000 & 11972850 & 0.132000 & 0.057000 & 0.076000 & 1878.000 & 0.110000 \\
\hline Maximum & 0.442000 & 29643236 & 0.542000 & 0.246000 & 0.287000 & 9502.000 & 0.416000 \\
\hline Minimum & 0.003000 & 1492526. & 0.024000 & 0.003000 & 0.004000 & 1116.000 & 0.004000 \\
\hline Std. Dev. & 0.121234 & 7061938. & 0.103993 & 0.058041 & 0.063469 & 1875.403 & 0.091910 \\
\hline Skewness & 1.457224 & 0.760316 & 2.077783 & 1.559750 & 1.211592 & 2.249835 & 1.412363 \\
\hline Kurtosis & 4.033874 & 3.218722 & 8.713315 & 4.940056 & 4.762082 & 8.191768 & 4.997351 \\
\hline Jarque-Bera & 10.75826 & 2.655180 & 56.14953 & 15.18198 & 10.09885 & 53.10168 & 13.46455 \\
\hline Probability & 0.004612 & 0.265115 & 0.000000 & 0.000505 & 0.006413 & 0.000000 & 0.001192 \\
\hline Sum & 2.800000 & $3.25 \mathrm{E}+08$ & 3.975000 & 1.907000 & 2.319000 & 70636.00 & 3.324000 \\
\hline Sum Sq. Dev. & 0.382142 & $1.30 \mathrm{E}+15$ & 0.281179 & 0.087588 & 0.104735 & 91445531 & 0.219633 \\
\hline Observations & 27 & 27 & 27 & 27 & 27 & 27 & 27 \\
\hline
\end{tabular}

\section{Result and Discussion}

Using the proposed model and focusing on the ratio estimation as well as the rate of return in the main topic of the regression model that was created. The proposed model will then be able to see and assist in the estimates and trends of the company's economic returns. There could be several scenarios for financial ratios in use, but in this study only used one type of proposal model. Using the time series data model consisting of 30 financial statements of companies listed on the BEI, the results of the study can be for the regression model presented in table 2 below: 
Table 2 : Regression statistic research

\begin{tabular}{|c|c|c|c|c|}
\hline \multicolumn{5}{|c|}{ Dependent Variable: Y } \\
\hline Variable & t-Statistic & Prob. & $\mathrm{R}$-squared & 0.675843 \\
\hline $\mathrm{C}$ & 0.200558 & 0.8431 & $\begin{array}{l}\text { Adjusted R- } \\
\text { squared }\end{array}$ & 0.578596 \\
\hline $\mathrm{X} 1$ & 1.034064 & 0.3134 & F-statistic & 6.949764 \\
\hline $\mathrm{X} 2$ & -0.022013 & 0.9827 & $\begin{array}{l}\text { Akaike info } \\
\text { criterion }\end{array}$ & -2.581769 \\
\hline $\mathrm{X} 3$ & -0.660484 & 0.5165 & $\begin{array}{l}\text { Schwarz } \\
\text { criterion }\end{array}$ & -2.245811 \\
\hline $\mathrm{X} 4$ & -0.700527 & 0.4917 & $\begin{array}{l}\text { Hannan- } \\
\text { Quinn criter. }\end{array}$ & -2.481871 \\
\hline $\mathrm{X} 5$ & 2.334045 & 0.0301 & $\begin{array}{l}\text { Durbin- } \\
\text { Watson stat }\end{array}$ & 1.495758 \\
\hline X6 & 1.612022 & 0.1226 & $\begin{array}{l}\operatorname{Prob}(\mathrm{F}- \\
\text { statistic) }\end{array}$ & 0.000421 \\
\hline
\end{tabular}

Source : Proceed by software

From table 2 can be seen the results of the proposed regression model, indicating that there is no significant relationship between the rate of return on an economy with some other variable financial ratios. 1 of 6 variables that are used as the basis of significant value regression is variable $\mathrm{X} 5$, while for the variables $\mathrm{X} 1, \mathrm{X} 2, \mathrm{X} 3, \mathrm{X} 4$ and $\mathrm{X} 6$ does not show significant numbers related to level economic return of the company. The rate of $\mathrm{R}$ squared is high enough, $67.58 \%$, this can indicate the proposed regression is not pseudo, and at a decent value. However, if we see that the $F$ value of statistic is very significant, it can be explained that, as a whole variable X1 equal to X6 has a significant impact on the variable of economic returns, whereas when viewed one by one, only 1 variable contributes significantly. To support the model of the proposed regression results, then proceed with using the test wald as the results presented in table 3 below:

Table 3 : Walt test statistic research

\begin{tabular}{|l|l|l|l|}
\hline \multicolumn{2}{|l|}{ Wald Test: } & & \\
\hline Test Statistic & Value & df & Probability \\
\hline F-statistic & 0.625000 & $(2,20)$ & 0.5454 \\
\hline Chi-square & 1.250000 & 2 & 0.5353 \\
\hline Null Hypothesis: C(2)=0,C(2)=2*C(3) & \\
\hline Null Hypothesis Summary: & 0.129679 & 0.125407 \\
\hline Normalized Restriction (=0) & Value & Std. Err. \\
\hline C(2) & & 0.125407 \\
\hline C(2) - 2*C(3) & & \\
\hline
\end{tabular}

Source : Proceed by software

Wald test is used to see whether the regression model proposed can provide an explanation description to support the results that have been encountered in table 2 above the proposed regression model. Seen results are also not significant, with the use of matrix as presented in Table 3. Probability is generated at 0.5454 and F statistic value of 0.625 . From the results of this wald test supports the findings that have been in the can of the regression model proposed in this study. This is not in line with the explanation with previous research done, if some variable of economic return rate have significant impact to variable of financial ratio owned by company. To see the regression modeling that is created and in can, is as follows:

Table 4 : Command estimation statistic research

Estimation Command:

LS Y C X1 X2 X3 X4 X5 X6

Substituted Coefficients:

$\mathrm{Y}=0.00693809402003+0.12967850683 * \mathrm{X} 1-1.02530426645 \mathrm{e}-10 * \mathrm{X} 2-0.369647411449 * \mathrm{X} 3-0.452451742781 * \mathrm{X} 4+1.6171670704 * \mathrm{X} 5+$ $1.96621790974 \mathrm{e}-05 * \mathrm{X} 6$

Source : Proceed by software

The results of the command in table 4 show the relationship between the rate of forecasting the value of the company's economic returns with some financial ratios of the company. Under the conditions of the proposed non linear model, the financial factor or ratios in use may be influenced by other economic dimensions, depending on all economic conditions. It could be that radical changes can occur in terms of financial ratios, but the proposed model can be an 
analytical tool that is considered useful and important and can complement each other in the analysis of the company's economic returns.

\section{Conclusion}

By looking at the progress and development in society in a modern way, which is considered stable, make some phenomena in various activities, not least in the field of economics and corporate finance. Using a proposed model of financial performance and economic performance of a company, making a quantitative stepping and leap, by exploiting diversions and the use of adequate methods or techniques, will get various interpretations of the overall outcome. Starting from the proposed model of analysis that is made, to measure the company's economic performance, to calculate the rate of return will be received, then there will be a tendency on other things to be dependent on the performance of others in the company's finances. In this study it provides an initial step and wishes to develop the proposed statistical model, and can provide disclosure at the company's economic returns - and refers to other fundamental factors and indicators, to view and express indirectly the financial performance within the firm or the performance of the company economically. Multiple regression proposed models can be developed, by capturing the data of companies listed on the BEI using statistically assisted software.

Ethical clearance - Not required

Source of funding- Self

Conflict of Interest - Nil

\section{References}

[1] Gersl A., Hermanek J. Financial stability indicators: advantages and disadvantage of their use in the assessment of financial system stability, CNB Financial Stability Report 2006, Thematic Article 2, pp. 69-79, (2006)

[2] Kahle, K.M., Stulz, R. M. Financial Policies, Investment, and the Financial Crisis: Impaired Credit Channel or Diminished Demand for Capital?, Fisher College of Business Working Paper No. 2011 $-3,(2011)$.

[3] Kolb, R. W. Lessons from the Financial Crisis - Causes, Consequences, and Our Economic Future, John Wiley \& Sons, Inc., Hoboken, New Jersey, (2010).

[4] Durante F., et, all Spatial contagion between financial markets: a copula-based approach. Applied Stochastic Models in Business and Industry 26 (5), (2010).

[5] Siedlecka, U., and Siedlecki, J., Optymalizacja taksonomiczna. Kraków: Wydawnictwo AE Kraków, (1990).

[6] Siedlecki, R. and Papla, D. Conditional correlation coefficient as a tool for analysis of contagion in financial markets and real economy indexes based on the synthetic ratio, Procedia - Social and Behavioral Sciences 220, 452-461, doi: 10.1016/j.sbspro.2016.05.520, (2016).

[7] Albulescu, C.T. Banks' Profitability and Financial Soundness Indicators: A Macro-Level Investigation in Emerging Countries, Procedia Economics and Finance 23, 203-209, doi: 10.1016/S2212-5671(15)00551-1, (2015).

[8] Gutu, L.M. et, all The macroeconomic variables' impact on industrial production in the context of financial crisis, Procedia Economics and Finance 32, 1258-1267, doi: 10.1016/S22125671(15)01503-8, (2015).

[9] Indrabudiman, Amir. Descriptive Analysis Stock Price with Zmijewski Bankruptcy Model to Total Assets on Stock Prices. International Journal of Scientific Research in Science and
Technology (IJSRST) Volume 3 Issue 6 Print ISSN: 2395-6011, Online ISSN: 2395-602X, (2017).

[10] Indrabudiman, Amir. Does Social and Environmental Disclosure Affect Stock Price? Evidence From Indonesian. International Journal of Economic Research Vol. 14, Number 1. ISSN: 09729380, (2017).

[11] Indrabudiman, Amir and Septihandayani, Wuri. Intellectual Capital and firm value: Evidence From Indonesia. International Journal of Pure and Applied Mathematics Volume 117 No. 15 2017, 885-891. ISSN: 1311-8080 (printed); ISSN: 1314-3395 (online), (2017)

[12] Indrabudiman, Amir. Social Enterprise Characteristics and Environmental Disclosures in Annual Reports of Mining Companies of Indonesia. International Journal of Management, Accounting \& Economics. Vol.2, No.1: 41-56, ISSN: 2412-0642, (2016).

[13] Indrabudiman, Amir. Relationship Between Consumer Price Index and Producer Price Index in Indonesia with Large mode Econometrics. International journal of Business Quantitative Economics and Applied Management Research vol. 2, Issue 6, ISSN: 2349-5677, (2015).

[14] Indrabudiman, Amir, Wuri Septi Handayani, Dewi P. Faeni Implementation of Importance Performance Analysis Methods as Government Internal Supervisory Apparatus (GISA) Performance Measurements in Indonesian Provinces. Journal of Advanced Research in Dynamical and Control Systems Vol. 9, Special issue 16, p530-545. ISSN: 1943-023X, (2017).

[15] Septihandayani, Wuri Unit Root and VAR of Macroeconomics Variables On Stock Returns and Deviden S\&P. SSBRN Symposium , Bali 4-5 August, 2016. Conducting Interdisciplinary Research. ISBN: 978-602-74915-0-2, (2016). 